\title{
Post-deposition Weathering of Pb-rich Particles From a Pb-Zn Smelting and Refining Factory Under Semiarid Conditions
}

\author{
Martin Federico Soto-Jiménez ( $\nabla$ martin@ola.icmyl.unam.mx ) \\ Universidad Nacional Autónoma de México \\ Sarahi Roos-Muñoz \\ Tecnológico Nacional de México, Instituto Tecnológico de Mazatlán \\ Sarahi Soto-Morales \\ Tecnológico Nacional de México, Instituto Tecnológico de Mazatlán \\ Laura Elena Gómez-Lizarrága \\ Universidad Nacional Autónoma de México \\ Lauro Bucio-Galindo \\ Universidad Nacional Autónoma de México. Ciudad Universitaria
}

\section{Research Article}

Keywords: Urban dust, Lead minerals, Pb bioavailability

Posted Date: August 26th, 2021

DOI: https://doi.org/10.21203/rs.3.rs-807064/v1

License: (c) (i) This work is licensed under a Creative Commons Attribution 4.0 International License. Read Full License 


\section{Abstract}

In this study, urban dust samples were collected at $1 \mathrm{~km}$ radius surrounding one of the largest $\mathrm{Ag}-\mathrm{Cd}-\mathrm{Pb}-\mathrm{Zn}$ smelting and refining complex in the world (Met-Mex Peñoles), which is in operation in Torreón (North México) since 1901. Metal-rich particles in urban dust were analyzed for elemental composition, and $\mathrm{Pb}$-rich particles were identified, characterized, and analyzed for mineral identification by using conventional techniques such as scanning electron microscopy (SEM), Energy Dispersive X-Ray Spectroscopy (EDS), and X-ray powder diffraction (XRD). Pb-rich particles showed a variety of sizes and morphologies and different contents of $\mathrm{Pb}$ and other elements. $\mathrm{Pb}$-rich particles were related to the fugitive and non-controlled emissions from Met-Mex Peñoles. Galena occurs in individual and metal-rich agglomerate particles. The presence of secondary $\mathrm{Pb}$ minerals (e.g., $\mathrm{Pb}$ carbonates, $\mathrm{Pb}$ sulfate, and $\mathrm{Pb}$ oxides) evidenced the weathering in $\mathrm{Pb}$-rich particles and metal-rich agglomerates. Secondary $\mathrm{Pb}$ minerals are incorporated in finer particles than original sulfide minerals, and they are also more concentrated in $\mathrm{Pb}$ and chemically more available than galena for the environment and humans. Physical-chemical transformations on the weathered $\mathrm{Pb}$-rich particles are increasing the availability and toxicity of lead in the urban dust and the potential impacts on the environment and human health.

\section{Introduction}

Fugitive and non-controlled metal-rich particles emissions from mining and non-ferrous metallurgical are the main source of metals to the atmosphere (Bollhöfer \& Rosman, 2001), and then to the urban environments, biota, and humans (Gulson et al., 1995). The physical and chemical properties of the metal-rich particles in urban impacted by mining-metallurgical activities depend on the processed mineral, industrial stage, and the emission controls implemented. In the case of $\mathrm{Ag}-\mathrm{Cd}-\mathrm{Pb}-\mathrm{Zn}$ smelter and refineries complexes, metal-rich particles are emitted to the atmosphere in a variety of sizes, morphologies, and elemental and mineral composition (Adamo et al., 1996; Gregurek et al., 1998, 1999; Ohmsen, 2001; Knight \& Henderson, 2005, 2006). These metal-rich particles contain high contents of potentially toxic elements (PTE) including As, $\mathrm{Cd}, \mathrm{Cu}, \mathrm{Hg}, \mathrm{Mn}, \mathrm{Pb}, \mathrm{and} \mathrm{Zn}$.

Metal-rich particles emitted from smelter and refineries complexes are not inert, but they are subject to weathering processes that involve a set of transformations of physical and chemical properties during their transport, atmospheric precipitation, and post-deposition (Chopin \& Alloway, 2007; Ettler et al., 2014a,b; Sobanska et al., 2016). The progress of the weathering processes on the metal-rich particles depends on the prevailing conditions in deposition environments (e.g., oxidizing condition, water content, temperature, $\mathrm{pH}$, microorganisms, and presence of other inorganic and organic compounds).

In Torreón, located on an arid to semiarid climate region in northern México, is installed one of the worldwide largest Ag-Cd-Pb-Zn smelters and refining complexes (Mex-Mex Peñoles), which is in operation since 1901. Mex-Mex metallurgical complex has been a primary source of metal-rich particles and PTE to rural and urban areas in Torreón since decades ago (Escobar-Márquez et al., 1964; Viniegra et al., 1964; Valdés-Pérezgasga \& Cabrera-Morelos, 1999; Benin et al., 1999; Soto-Jiménez \& Flegal, 2011a,b). Recently, Soto-Jimenez \& Flegal (2021) estimated the Pb emitted by the complex over the past 118 years in $23,350-27,580$ tons. The largest emission inventory (63-75\%) occurred during the pre-1960 period when fugitive and emission controls were negligible.

The alterations of the physicochemical properties of $\mathrm{Pb}$-rich smelting particles post-deposition, emitted for decades, related to weathering has not yet been investigated in Torreon. The weathering process of $\mathrm{Pb}$-rich particles influence the metal mobility and availability and exacerbate the potentially deleterious effects of $\mathrm{Pb}$ on human health and the environment, but little knowledge exists about these mechanisms in arid or semiarid climate regions (Root et al., 2015), such as Torreón city.

In the present research, metal-rich particles present in urban environmental dust collected in Torreón were observed for physical characterization and weathering by scanning electron microscopy (SEM). Then, the metal-rich particles were bombardment by an electron beam to characterize the elemental composition by Energy Dispersive X-Ray Spectroscopy (EDS). Finally, we focused on the weathered Pb-rich particles for particle size distribution, morphology, and elemental and mineral composition by using SEM-EDS and X-ray powder diffraction (XRD) techniques. Mineral analyses were compared by the mineralogical database on the International Centre for Diffraction Data (https://www.icdd.com/).

\section{Methods}

\section{Background Met-Mex}

Details about the historical Ag-Cd-Pb-Zn smelter and refineries complex, Met-Mex Peñoles, are provided by Soto-Jiménez \& Flegal (2021). Briefly, the smelter in Torreón was built in 1901 to treat the ores concentrates of Peñoles mines. A few years later, become one of Mexico's largest industrial complexes, producing Pb, Ag, and As. Torreón smelter was competing with The ASARCO El Paso lead smelter, constructed in the late 19th century, to process ore from the rich mining districts of Chihuahua (Marcosson, 1949). Beginning 1960s, the facility was expanded and diversified to process other metals and chemical by-products over time. The expansion included a $\mathrm{Zn}$ smelter- electrolytic refinery plant in 1961 ; three $\mathrm{H}_{2} \mathrm{SO}_{4}$ plants in 1961,1970 , 1976; improvements in those plants in 1988 and 2000, an Ag refinery (1975), and $\mathrm{NH}_{4} \mathrm{SO}_{4}$ fertilizer and SO 2 liquid plants in 1990. Presently, Met-Mex is divided into two circuits: the $\mathrm{Pb}-\mathrm{Ag}$ and $\mathrm{Zn}$ circuits. The $\mathrm{Pb}-\mathrm{Ag}$ circuit has the $\mathrm{Pb}$ smelter, where $\mathrm{Ag}$ - $\mathrm{Cd}-\mathrm{Pb}$ - $\mathrm{Zn}$ concentrates are processed to produce $\mathrm{Pb}$ bullion, and the $\mathrm{Ag}-\mathrm{Pb}$ refinery that receives $\mathrm{Pb}$ bullion and other byproducts to produce $\mathrm{Au}, \mathrm{Ag}, \mathrm{Pb}$, and $\mathrm{Bi}$. The installed capacity in the $\mathrm{Pb}$ smelter is 180,000 tons of $\mathrm{Pb}$ bullion, and that of the $\mathrm{Ag}$ - $\mathrm{Pb}$ refinery is 180,000 tons of $\mathrm{Pb}, 118$ million oz of $\mathrm{Ag}, 1.9 \mathrm{million}$ oz of $\mathrm{Au}$, and 1,440 tons of $\mathrm{Bi}$. The zinc circuit, where an electrolytic process to produce refined Zn treats, Zn concentrates has an installed capacity of 360,000 tons of Zn ingots (Peñoles 
Report, 2017). In 2018, the production volumes were Au 1.13 million oz, Ag 64.9 million oz, Pb 112,840 ton, Zn 228,842 ton, Bi 333 ton, and 639 ton of Cd (Peñoles Report, 2018).

\section{Background Torreón city}

Torreón city, located in northern México, has a population of $>725,000$ (INEGI, 2021). It is the largest of four sister cities of the metropolitan "La Laguna" zone (Torreón and Matamoros in Coahuila, and Gómez-Palacios and Lerdo in Durango), with a population > 1.6 million inhabitants (INEGI, 2021). The "La Laguna" region is characterized by an arid to semiarid climate, with very low precipitation (mean $225 \mathrm{~mm} \mathrm{y}^{-1}$ ), elevated evaporation (mean 2,000 $\left.\mathrm{mm} \mathrm{y}^{-1}\right)$, and average summer and winter temperatures of 31 and $16^{\circ} \mathrm{C}$, respectively. Relative humid average $38 \%$.

Based on a wind vectorial analysis of 10 years dataset, the prevalent wind in the region goes from northwest to southeast during winter, and from northeast to southwest for the rest of the year. Thermic inversions are common from November to March, these events exacerbate the ambient pollution in the city because the pollutants are retained in the atmospheric upper layers. Besides, powerful convection flows are generated as the result of contact between the compressed cold air and warm air, which results in resuspension and mobilization of particles to the atmosphere. The resuspension may result in dust storms (in the region called tolvanera) that emit large amounts of dust into the atmosphere with the potential to be transported long distances.

The topography is characterized by a mountain chain of the Sierra de las Noas ( $>400 \mathrm{~m}$ high; $1500 \mathrm{~m}$ ) and the flat basin of Agua Naval River. This river divides the cities of Gomez and Lerdo, and then flows southward to Torreón City. The North-South-oriented Sierra de las Noas hill is another natural limit of the city.

\section{Sample collection}

Atmospheric particulate matter sinking by dry deposition was collected in the urban area in Torreón in situated cross-sectionally sites, depending on the measured wind direction and at specific distances from the Met-Mex complex (Fig. 1). Eight acrylic frame plates ( $\left.1 \mathrm{~m}^{2}\right)$ recovered with low-density polyethylene (LDPE) were rotativity placed in different sites covering most of the city area and the prevailing weather conditions in the region. The deposition devices were collected above the home ceiling (>3 m height) for 12 to 48 hours under stable weather conditions (no rain was observed and samples for dust storm events were excluded). A total of 18 aerosol samples were collected in the urban area of Torreón in a 2-km radius from Met-Mex, including 3 samples representing the urban background obtained in three sites far away from the complex emissions or another known source of lead.

The background composite samples were collected at 4 (25.520, -103.442), 5.3 (25.531, -103.438), and 7.2 km (25.576, -103.395) to northeast from MetMex. Sampling surveys were conducted in winter (January-February 2015) and spring-summer (April-June 2017).

\section{SEM, EDS, and XRD analysis}

Aerosols samples were oven-dried $\left(65-70^{\circ} \mathrm{C}\right)$ for $72 \mathrm{~h}$ and then equilibrated in a desiccator for $48 \mathrm{~h}$. Aliquots of urban dust samples were examined under the scanning electron microscope (SEM) to determine the size and morphology. Few milligrams of urban dust samples were prepared by sprinkling aliquots onto a carbon-impregnated tape and mounted in aluminum holders. Measurements were made using a Zeiss model EVO MA10 SEM at high vacuum operating with a beam scan accessory V $(20 \mathrm{kV})$. High definition and high magnification SEM images for each sample (triplicated of $150 \times 150 \mathrm{~mm}$ area per sample) were taken at four magnifications, namely 500x, 1500x, 3000x, and 6000x obtained by backscattered electron detector. The elements with a large atomic number (e.g., Pb, atomic number $Z=82$ ) produce an intense bright white color because more backscattered electrons are emitted when the primary electron beam interacts with the nuclei of the element. The high-resolution SEM images were analyzed by a softwareassisted method (ImageJ software developed by the U.S. National Institutes of Health) to determine the particles diameter. Particle counting was visually done in the magnified SEM images. Particles were classified in five different size fractions based on their deposition efficiency along the respiratory tract (Fig. 2). Briefly, (1) > $10 \mu \mathrm{m}$ : inhalable since they can easily enter the nose and mouth, $(2)<10 \mu \mathrm{m}\left(\mathrm{PM}_{10}\right)$ : thoracic since they can penetrate deep in the respiratory system and generally deposited by impaction in the extra thoracic airway region, $(3)<4 \mu \mathrm{m}$ : respirable because they are small enough to pass completely through the respiratory system and enter the bloodstream and are deposited by impaction in the tracheobronchial airway in the deep lungs, (4) $<2.5 \mu \mathrm{m}\left(\mathrm{PM}_{2.5}\right)$ : fine because penetrate the smaller airways and are deposited by sedimentation in the peripheral lung region in the tracheobronchial airway close to alveolar interstitium, and $(5)<0.1 \mu \mathrm{m}\left(\mathrm{PM}_{0.1}\right)$ : ultrafine because penetrate the smaller airways and is deposited by diffusion often in the alveolar interstitium. Also, inhalable particles were divided in large (>10 to $25 \mu \mathrm{m})$, and giants (>25 $\mu \mathrm{m})$.

The deposited aerosol samples were analyzed by Energy Dispersive X-Ray Spectroscopy (EDS) detector (Bruker XFlash 4010) coupled to the Zeiss EVO MA10 SEM (Full Scale: $20 \mathrm{KeV}(20 \mathrm{eV} / \mathrm{ch}, 1 \mathrm{Kch})$, Acc. Volt: $20.0 \mathrm{KV}$, Probe Current: 1.781E-08 A). The sample preparation for SEM-EDS analysis agreed to Bern et al. (2009) procedure. Briefly, aliquot of sample was weighted (0.1-0.2 g), splitted to obtain a sample mass between 10 and 20 mg, placed in suspension with isopropanol ( $10 \mathrm{mg}$ dust $\left.\mathrm{mL}^{-1}\right)$, transferred to polycarbonate substrate $(0.4 \mu \mathrm{m}$ pore size filters affixed to $13 \mathrm{~mm}$ aluminum stubs with conductive carbon adhesive tabs), air-dried, and coated with a thin $(\sim 100 \AA)$ conductive carbon film using a carbon evaporator with a rotating stage. Metal-rich particles with different sizes and morphologies were analyzed by EDS-SEM for quantification of elemental composition. Then, we focused on the identification of minerals in the metallic particles rich in $\mathrm{Pb}$ based on the chemical composition analyses (in weight \%) and morphology of the SEMEDS analysis.

Because of the complexity for the identification of phases within the urban dust, X-ray powder diffraction analysis was done on selected Pb-rich particles and metal-rich agglomerates slag as an independent method verifying the mineralogy of SEM-EDS. XRD measurements were done with a Philips PW 1729 X-ray diffractometer at a voltage of 40 kV and current of 30 mA using Co Ka (1.79 ̊) and Cu Ka radiation (1.54 Å), respectively. Diffraction patterns 
from $\mathrm{Pb}$-rich particles were collected over a scan range of $5-75^{\circ} 2 \theta$ with a step size of $0.02^{\circ} 2 \theta$ and dwell times of $4-10 \mathrm{~s}$. The identification of the probable minerals was supported by consulting the mineralogical database on the International Centre for Diffraction Data (https://www.icdd.com/ ).

\section{Results}

\section{Size and morphological characteristics of metal-rich particles}

Figures 3 show microphotography of the typical metal-rich particles and metal-rich agglomerates slag observed in the adjacent urban areas in Torreón at $<2 \mathrm{~km}$ radius to Met-Mex. Results of SEM examination evidenced that metal-rich particles consist primarily of individual angular grains, spheres, rice grains type, and tiny discrete particles. Amalgamations of spheres and other metal-rich agglomerates particles were also observed. The size distribution of individual and agglomerates particles ranged from ultrafine $(<0.1 \mu \mathrm{m})$ to giants $(50-70 \mu \mathrm{m}$ diameter or length). Most of metallic particles were in the range of fine $(<2.5 \mu \mathrm{m})$ to large $(>10$ to $25 \mu \mathrm{m})$. In terms of numbers of metal-rich particles, distribution was $<0.1 \mu \mathrm{m} 30-49.2(\mathrm{median} 33.5 \%),<2.5 \mu \mathrm{m}$ $25-30.6(27.8 \%),<4 \mu \mathrm{m} 14.7-22.2(15.8 \%),<10 \mu \mathrm{m} 8.2-16.7(13.9 \%)$, and $>10 \mu \mathrm{m} 6.1-19.4(9.1 \%)$. In terms of mass, the deposited dry aerosol distribution is $1.3-4.9(1.9 \%)$ for particles $<0.1 \mu \mathrm{m}, 2.7-8.4(5.6 \%)$ for $<2.5 \mu \mathrm{m}, 1.3-12.3(7.6 \%)$ for $<4 \mu \mathrm{m}, 22.4-51.8(50.9 \%)$ for $<10 \mu \mathrm{m}$, and $23-$ $71.6(33.9 \%)$ for $>10 \mu \mathrm{m}$. Although the ultrafine and fine particles are more abundant than remnants sizes, in terms of counts, represents $<15 \%$ of the emitted mass because smaller sizes contribute less to the total mass.

\section{Elemental composition of rich-metal particles}

An elemental composition analysis was conducted by SEM-EDS in the most common metallic particles observed in each airborne dust sample collected in the urban environmental area around Met-Mex. Results of the quantification of elemental abundances (in weight \%) are summarized in Table 1 and displayed in Figs. 4 and 5. Lead peaks in EDS spectra observed in urban dust collected in the Met-Mex vicinity were differentiated from other metals (e.g., $\mathrm{Al}, \mathrm{Ag}, \mathrm{Cd}, \mathrm{Cu}, \mathrm{Fe}, \mathrm{Hg}$, and $\mathrm{Zn}$ ), metalloids ( $\mathrm{As}, \mathrm{Bi}$, and $\mathrm{Si}$ ), and not metals ( $\mathrm{Ca}, \mathrm{Cl}, \mathrm{Mg}, \mathrm{P}$, and $\mathrm{S}$ ), which appear together in the low part of the spectra.

Table 1

Elemental composition of most representative metal-rich particles (\% in weight of element) in urban dust collected in Torreón (northern Mexico)

\begin{tabular}{|c|c|c|c|c|c|c|c|c|c|c|c|c|c|c|c|c|c|c|}
\hline \multirow[b]{2}{*}{ Element } & \multicolumn{3}{|c|}{ Urban background } & \multicolumn{15}{|c|}{ Urban environmental samples in the vicinity of the Met-Mex Peñoles } \\
\hline & 1 & 2 & 3 & 1 & 2 & 3 & 4 & 5 & 6 & 7 & 8 & 9 & 10 & 11 & 12 & 13 & 14 & 15 \\
\hline \multicolumn{4}{|c|}{ Size class $(\mu \mathrm{m})$} & $<4$ & $<4$ & $>10$ & $>10$ & $\begin{array}{l}<.5 \\
2 .\end{array}$ & $\begin{array}{l}<.5 \\
2 .\end{array}$ & $>10$ & $\begin{array}{l}<.1 \\
0.1\end{array}$ & $>10$ & $\begin{array}{l}<.5 \\
2.5\end{array}$ & $\begin{array}{l}< \\
0.1\end{array}$ & $>10$ & $\begin{array}{l}<.5 \\
2.5\end{array}$ & $<10$ & $<10$ \\
\hline $\mathrm{Ag}$ & 0.3 & ND & 0.1 & ND & 0.2 & 0.03 & 0.8 & 0.2 & ND & 0.1 & ND & ND & ND & 1.3 & 0.5 & 1.9 & 0.0 & 0.6 \\
\hline $\mathrm{Al}$ & 12.7 & 17.2 & 2.2 & ND & 2.1 & 0.0 & 1.0 & 1.4 & ND & 0.01 & 1.0 & 10.3 & 0.05 & 0.7 & 0.6 & 0.0 & 0.0 & 1.2 \\
\hline As & 2.5 & 1.5 & 0.8 & 1.4 & 1.7 & ND & 1.3 & 1.0 & ND & ND & ND & 3.4 & 0.04 & 0.5 & 0.8 & 0.2 & 0.0 & 1.3 \\
\hline $\mathrm{Bi}$ & ND & ND & ND & ND & ND & 0.03 & ND & 7.2 & 2.1 & ND & 7.2 & ND & 2.5 & ND & ND & ND & 1.6 & 0.0 \\
\hline $\mathrm{Ca}$ & 15.9 & 10.4 & 8.0 & 2.3 & 5.7 & 0.3 & 1.6 & 2.7 & 2.6 & 0.8 & 2.8 & ND & ND & ND & ND & ND & 72.2 & 8.7 \\
\hline $\mathrm{Cd}$ & ND & ND & ND & 5.1 & 1.5 & 0.1 & 0.4 & 2.2 & ND & ND & ND & 2.8 & ND & ND & 0.2 & 1.3 & ND & 3.3 \\
\hline $\mathrm{Cl}$ & ND & 0.1 & 2.7 & ND & ND & ND & ND & ND & ND & ND & ND & ND & ND & ND & ND & ND & ND & ND \\
\hline $\mathrm{Cu}$ & 6.3 & 5.1 & 5.6 & 5.1 & 6.2 & 4.9 & 5.7 & 5.8 & 6.1 & 4.1 & 6.0 & 6.9 & ND & ND & ND & 14.1 & 7.7 & 9.5 \\
\hline $\mathrm{Fe}$ & 6.0 & 13.9 & 59.0 & 0.6 & 4.1 & 3.3 & 63.6 & 2.9 & 0.4 & 5.3 & 0.4 & 9.3 & 0.4 & ND & 12.3 & 2.2 & 9.1 & ND \\
\hline $\mathrm{Hg}$ & ND & ND & ND & ND & ND & 0.05 & ND & ND & ND & ND & 0.2 & ND & 0.6 & 0.3 & 0.0 & 0.3 & 0.0 & ND \\
\hline $\mathrm{Mg}$ & ND & 0.6 & ND & ND & ND & ND & ND & ND & 1.5 & 0.3 & ND & ND & ND & ND & ND & ND & ND & ND \\
\hline$P$ & 0.6 & 0.7 & 3.0 & 2.5 & 1.9 & 0.1 & 0.1 & 1.0 & 0.2 & 0.1 & ND & ND & ND & ND & ND & ND & ND & 9.8 \\
\hline $\mathrm{Pb}$ & ND & 0.7 & 2.6 & 42.4 & 62.5 & 0.0 & 17.4 & 51.0 & 73.2 & 0.3 & 70.2 & 7.8 & 87.2 & 86.0 & 1.7 & 65.6 & ND & 57.1 \\
\hline$S$ & 1.1 & ND & 0.8 & 3.6 & 2.9 & 0.03 & 3.4 & 4.9 & 1.2 & 0.4 & 8.6 & 5.4 & 8.7 & 9.6 & 2.5 & 10.9 & 1.7 & 0.7 \\
\hline $\mathrm{Si}$ & 52.9 & 48.6 & 15.2 & 1.5 & 6.9 & 0.9 & 2.9 & 16.5 & 1.6 & 0.7 & 2.2 & 45.0 & 0.6 & 1.6 & 2.5 & 2.0 & 1.2 & 5.0 \\
\hline $\mathrm{Ti}$ & 1.7 & 1.0 & 0.01 & ND & ND & ND & ND & ND & 0.2 & 0.01 & 0.4 & ND & ND & ND & ND & ND & ND & ND \\
\hline $\mathrm{Zn}$ & ND & ND & ND & 35.4 & 4.3 & 90.3 & 1.7 & 3.1 & 10.9 & 87.8 & 1.10 & 9.2 & ND & ND & 79.0 & 1.4 & 6.4 & 2.8 \\
\hline
\end{tabular}


$\mathrm{Fe}, 6 \% \mathrm{Cu}, 1.5 \% \mathrm{Cd}, 0.7 \% \mathrm{Al}, 0.3 \% \mathrm{Ag}$, and $0.2 \%$ of Ti and $\mathrm{Hg}$. Metalloids in Pb-rich particles included Bi (median $2.1 \%)$, Si ( $2 \%$ ), and As (1\%). Non-metal contents showed median values of $3.4 \%$ for $\mathrm{S}, 2.7 \%$ for $\mathrm{Ca}, 0.6 \%$ for $\mathrm{P}$, and $0.9 \%$ for $\mathrm{Mg}$.

The chemical analysis among different Pb-rich particles observed in urban dust collected in surrounding Met-Mex sites, distinguished in size and morphological, showed significant differences among them. However, Pb-rich particles in the same or different sample, with similar morphologies characteristics, showed similarity in the elemental composition. Overall, a relationship was observed between the particle size and the elemental composition, regarding $\mathrm{Pb}$ content (Table 1; Fig. 4-5). Most of the ultrafine and fine particles ( $<2.5 \mu \mathrm{m})$ showed higher contents of $\mathrm{Pb}$ (70-90\% of $\mathrm{Pb}$ ) and less proportion of other elements than large ( $>10$ to $25 \mu \mathrm{m})$ with $\mathrm{xx}-\mathrm{yy} \%$, and giant particles $(>25 \mu \mathrm{m})$ with $<25 \%$ of all $\mathrm{Pb}$ mass.

In Table 1, we also included the elemental composition of composite samples collected far away from Met-Mex (at 4, 5.3, and 7.2 km to northeastward), representing the urban background in Torreón. Significant differences were observed between metal-rich particles collected far away versus those collected in the vicinity of Met-Mex. In background urban samples, the median contents of elements were $\mathrm{Ag} 0.2 \%, \mathrm{Al} 12.7 \%, \mathrm{As} 1.5 \%, \mathrm{Ca} 10.4 \%, \mathrm{Cl} 1.4 \%$, Cu $5.6 \%$, Fe $13.9 \%$, Mg 0.6\%, P 0.7\%, Pb 1.7\%, S 1\%, Si 48.6\%, Ti 1\%, while Bi, Cd and $\mathrm{Zn}$ were undetected. The composition of the background samples is representative of natural soils in the region. Overall, $\mathrm{Pb}$ contents in metal-rich particles collected far away were significantly lower than those collected around $1 \mathrm{~km}$ radios Met-Mex, while levels of Si and Al were significantly higher.

\section{Identification of most probable minerals in metal-rich particles}

Because of the complexity of the chemical composition (metals $\mathrm{Al}, \mathrm{Ag}, \mathrm{Cd}, \mathrm{Cu}, \mathrm{Fe}, \mathrm{Hg}$, and $\mathrm{Zn}$; metalloids $\mathrm{As}, \mathrm{Bi}$, and $\mathrm{Si}$, and non-metals $\mathrm{Ca}$, Mg, $\mathrm{P}$, and $\mathrm{S}$ ), $\mathrm{X}$-ray diffraction analyses, in a combination of SEM-EDS, were practiced in representative samples of urban dust with most common $\mathrm{Pb}$-rich particles for identification of minerals (Table 2). The presence of sulfur in the particle with $\mathrm{Pb}$ and $\mathrm{Zn}$ peaks indicates the presence of basic $\mathrm{Pb}$ and $\mathrm{Zn}$ minerals, galena ( $\mathrm{PbS}$ ) and sphalerite ( $\mathrm{ZnS})$, in the urban dust samples collected in the vicinity of Met-Mex. Individual particles of galena ore and relicts of this mineral were observed into agglomerated pieces of slags. In many Ag-Cd-Pb-Zn mining districts in México, the predominant forms of $\mathrm{Pb}$ and $\mathrm{Zn}$ are galena and sphalerite, respectively. Thus, sulfide mineral concentrates are mostly processed to produce lead refined. The presence of galena and sphalerite is indicative of fugitive emissions of sulfide mineral concentrates, while metal-rich agglomerates slag containing galena, evidencing an incomplete smelting of those concentrates processed. 
Table 2

Major and minor mineral phases of $\mathrm{Pb}$ identified in metal-rich particles in urban dust samples collected in the $\mathrm{Pb}$ polluted urban environment area from Torreón (northern Mexico). Mineral phases are alphabetically ordered.

\begin{tabular}{|c|c|c|c|c|c|c|c|c|c|c|c|c|}
\hline \multirow[t]{2}{*}{$\mathrm{Pb}$ phase } & \multirow[t]{2}{*}{ Formulation } & \multicolumn{11}{|c|}{ Selected weathered $\mathrm{Pb}$-rich particles } \\
\hline & & 1 & 2 & 3 & 4 & 5 & 6 & 7 & 8 & 9 & 10 & 11 \\
\hline \multicolumn{13}{|l|}{ Major minerals } \\
\hline Anglesite & $\mathrm{PbSO}_{4}$ & & + & + & & & & + & + & $+?$ & + & + \\
\hline Cerussite & $\mathrm{PbCO}_{3}$ & & + & + & + & + & + & + & & & + & + \\
\hline Galena & $\mathrm{PbS}$ & + & + & + & & + & + & + & & + & + & $+?$ \\
\hline Hydrocerussite & $\mathrm{Pb}_{3}\left(\mathrm{CO}_{3}\right)_{2}(\mathrm{OH})_{2}$ & - & + & $+?$ & + & + & + & + & & & $+?$ & $+?$ \\
\hline Hydroxylpyromorphite & $\mathrm{Pb}_{5}\left(\mathrm{PO}_{4}\right)_{3}(\mathrm{OH})$ & + & $+?$ & $+?$ & + & & & & & & & $+?$ \\
\hline Litharge & $\mathrm{PbO}$ & & + & & & + & & & & & & + \\
\hline \multicolumn{13}{|l|}{ Minor minerals } \\
\hline Caledonite & $\mathrm{Pb}_{5} \mathrm{Cu}_{2}\left(\mathrm{SO}_{4}\right)_{3}\left(\mathrm{CO}_{3}\right)(\mathrm{OH})_{6}$ & + & + & + & + & & & + & & & + & + \\
\hline Crimsonite & $\mathrm{PbFe}_{2}\left(\mathrm{PO}_{4}\right)_{2}(\mathrm{OH})_{2}$ & & + & + & & & & + & & & & + \\
\hline Esperite & $\mathrm{PbCa}_{2} \mathrm{Zn}_{3}\left(\mathrm{SiO}_{4}\right)_{3}$ & + & $+?$ & $+?$ & + & + & & & & & & + \\
\hline Feinglosite & $\mathrm{Pb}_{2} \mathrm{Zn}\left(\mathrm{AsO}_{4}\right)_{2}$ & + & + & + & & & & & & & & + \\
\hline Friedrichite & $\mathrm{Pb}_{5} \mathrm{Cu}_{5} \mathrm{Bi}_{7} \mathrm{~S}_{18}$ & & & & & + & + & & + & & & $+?$ \\
\hline Galenobismutite & $\mathrm{PbBi}_{2} \mathrm{~S}_{4}$ & & & & & + & + & & + & & & \\
\hline Lautenthalite & $\mathrm{PbCu}_{4}\left(\mathrm{SO}_{4}\right)_{2}(\mathrm{OH})_{6}$ & + & + & + & + & & & & & & + & + \\
\hline Linarite & $\mathrm{PbCu}\left(\mathrm{SO}_{4}\right)(\mathrm{OH})_{2}$ & + & + & + & + & & & & & & + & \\
\hline Luddenite & $\mathrm{Cu}_{2} \mathrm{~Pb}_{2} \mathrm{Si}_{5} \mathrm{O}_{14}$ & & + & & & & & + & & & + & \\
\hline Massicot & $\mathrm{PbO}$ & & $+?$ & & & $+?$ & & & & & & $+?$ \\
\hline Vanackerite & $\mathrm{Pb}_{4} \mathrm{Cd}\left(\mathrm{AsO}_{4}\right)_{3}(\mathrm{Cl}, \mathrm{OH})$ & + & + & & + & & & & & & & + \\
\hline
\end{tabular}

Most of the particles and metal-rich agglomerates slag containing galena showed evidence of weathering. The microphotographs displayed the presence of secondary minerals in Pb-metal-rich particles (Fig. 6). XRD analysis evidenced the abundant presence of Pb carbonates, cerussite $\left(\mathrm{PbCO}_{3} \cdot 2 \mathrm{H}_{2} \mathrm{O}\right)$, and probably hydrocerrusite $\left(\mathrm{Pb}_{2} \mathrm{CO}_{3}(\mathrm{OH})_{2}\right)$. The cerussite was observed covering most of the weathered galena particles. Cerussite crystallizes in the orthorhombic system, being pseudo-hexagonal in form, present as contact twins with a heart-shaped outline, and reticulated growth of thin crystals form a delicate, snowflake-like mass on the weathering lead layer. Hydrocerussite crystals has also a hexagonal appearance, like cerussite.

Data also showed the presence of other secondary $\mathrm{Pb}$ minerals in Pb-rich particles, including litharge and/or massicot (Pb0), hydroxylpyromorphite $\left(\mathrm{Pb}_{5}\left(\mathrm{PO}_{4}\right)_{3}(\mathrm{OH})\right)$ and anglesite $\left(\mathrm{PbSO}_{4}\right)$. Other secondary $\mathrm{Pb}$ minerals surrounding galena particles containing $\mathrm{Cu}\left(\mathrm{linarite} \mathrm{PbCu}\left(\mathrm{SO}_{4}\right)(\mathrm{OH})_{2}\right.$, lautenthalite $\mathrm{PbCu}_{4}\left(\mathrm{SO}_{4}\right)_{2}(\mathrm{OH})_{6}$, luddenite $\left.\mathrm{Cu}_{2} \mathrm{~Pb}_{2} \mathrm{Si}_{5} \mathrm{O}_{14}\right)$, $\mathrm{Zn}$ (Feinglosite $\left.\mathrm{Pb}_{2} \mathrm{Zn}\left(\mathrm{AsO}_{4}\right)_{2}\right)$ and $\mathrm{Cd}\left(\right.$ vanackerite $\mathrm{Pb}_{4} \mathrm{Cd}(\mathrm{AsO})_{3}(\mathrm{Cl}, \mathrm{OH})$ ) were also identified. A list of minor secondary $\mathrm{Pb}$ minerals, probably present in urban dust in the Met-Mex vicinity were observed. However, more studies are required to differentiate among those complexes' structures, thus these were not included. Although XRD is the best method for mineral identification, additional physical or chemical tests can be required to distinguish one mineral from another with a similar crystalline structure. For example, Raman spectroscopy analysis that provides vibrational fingerprints of chemical compounds (Sobanska et al., 2016).

\section{Discussions}

\section{Morphologies and size distribution of metal-rich particles}

Non-data about the morphologies and size distribution of metal-rich particles emitted from the Met-Mex are available. However, metal rich-particles emitted from smelters consist largely of angular, spherical particles and agglomerates of small spherical particles. Angular particles are related to the fugitive emission of dust particles of concentrate ores and other raw material from the handling operations (e.g., transportation, storage, or use) and 
expelled materials not heated to the melting temperature (Ettler et al., 2016; Gregurek et al., 1999, Shukurov et al., 2014). Spherical and agglomeratebearing particles represent quenched melt droplets during smelting of $\mathrm{Pb}$ and $\mathrm{Zn}$ concentrate ores, and flue gas cleaning processes emitted by the smelter smokestack (Henderson et al., 1998, Gregurek et al., 1998, 1999, Knight \& Henderson, 2006, Lanteigne et al., 2012, 2014, Shukurov et al., 2014; Ettler et al., 2014a, 2016).

Sobanska et al. (1999) studied the morphology and size distributions of 'primary' dust emitted by typical pyrometallurgical lead smelters with dust filters, they found that $90 \%$ of the particle distribution was around $5 \mu \mathrm{m}$ and had no 'predominant morphology', while the remaining $10 \%$ was $10-20 \mu \mathrm{m}$. In smelter operation without dust filters, the presence of metal-rich particles and metal-rich agglomerates slag is common $>20 \mu \mathrm{m}$ (Cusano et al., 2017 ). Large particles $(>10 \mu \mathrm{m})$, including the agglomerates, can be released from fugitive concentrate ore during handling operations and by incomplete smelter operations, while the fine and ultrafine particles are mainly releasing from smelting and refining operations.

We did not study the metal-rich particle size distribution in function of distance to the smelter and refining factory, however, a higher number of larger particles were more present in closer samples to Met-Mex. It is expected that coarser particles are deposited in the vicinity of the factory and the surrounding urban environments, while the fine and ultrafine particles can travel longer distances far away from the complex (Csavina et al., 2011, 2012, 2014; Ettler, 2016).

\section{Mineral composition of weathered $\mathrm{Pb}$-rich particles}

Non-previous studies describing the mineralogy have been done in metal-rich particles emitted by the Ag-Cd-Pb-Zn smelter and refining complex in Torreón. Pb rich-particles emitted from the non-ferrous smelter and refining complexes contain a variety of compounds including sulfides (PbS, ZnS) and their oxidation products such as sulfates $\left(\mathrm{PbSO}_{4}\right)$, oxides $\left(\mathrm{PbO}, \mathrm{ZnO}, \mathrm{CdO}, \mathrm{As}_{2} \mathrm{O}_{3}\right)$, oxide-sulfates $\left(\mathrm{PbO} \cdot \mathrm{PbSO}_{4}\right), \mathrm{carbonates}\left(\mathrm{PbCO}_{3}\right), \mathrm{Cl}_{\text {-bearing phases }}$ $\left(\mathrm{PbClOH}, \mathrm{Pb}_{4} \mathrm{O}_{3} \mathrm{Cl}_{2}\right)$, as well as metallic elements $\left(\mathrm{Pb}^{\circ}, \mathrm{Cu}^{\circ}\right)$ and $\mathrm{Pb}$ silicates (Sobanska et al., 1999; Manceau et al., 2000; Ettler et al., 2020). The chemical composition of Pb-particles changes in time during the weathering (Spear et al., 1998; Piatak et al., 2004; Piatak \& Seal, 2010; Root et al., 2015). In this study, changes in the mineralogy of the Pb-rich particles historically emitted by $\mathrm{Pb}-\mathrm{Zn}$ smelting and refining activities evidence the progress in the weathering. The presence of other secondary minerals around pieces of galena (e.g., cerussite, litharge, and anglesite) is indicative that $\mathrm{PbS}$ has undergone partial oxidation in the urban environment (Hettiarachchi \& Pierzynski, 2004). The notable absence of Cl-bearing phases can be explained by the difficulty to identify non-crystalline phases by XRD and/or because they have high solubility, rapidly dissolved and mobilized into the environmental matrices (from aerosols to urban dust soils, to soils and water) (Ettler et al., 2005).

A lot of particles of galena or with galena incorporated are being converted into secondary minerals of $\mathrm{Pb}$, which is clear evidence of weathering processes occurring on these sulfide mineral particles. However, the presence of particles of galena in urban dust, as the primary phase, also denotes a slow kinetic weathering process (Rucker, 2000; Witt et al., 2013, 2014), considering that emissions started 120 years ago and more of the Pb-particles were emitted before the 1960s (Soto-Jiménez and Flegal, 2021).

\section{Implications for impacts on the environment and health of lead}

Lead contents in cerussite increase up to $77.5 \%$ and anglesite up to $74 \%$ compared to galena that contains $50-60 \%$ by mass. $\mathrm{Pb}$ carbonates and $\mathrm{Pb}$ sulfates are more soluble under gastric conditions than galena (Gasser et al., 1996; Ruby et al., 1999; Casteel et al., 2006; Argyraki, 2014; Bosso \& Enzweiler, 2008; Ettler et al., 2020). Thus, the weathering alterations of Pb-rich particles to finer particles, more concentrated in Pb, and forming secondary minerals, exacerbates the solubility, availability, and toxicity of the Pb in urban environments (Ettler et al., 2020; Spear et al., 1998). The Pbrich particles in weathering process are susceptible to be more accessible and available when are incorporated into the human body by different routes, including inhalation in aerosols, ingestion in soils and dust, and absorption by dermal contact (Birmili et al., 2006).

In this study, the alteration of the physical of Pb-rich particles is evidenced by changes in the particle size, elemental contents, and mineral composition. For example, secondary minerals are incorporated in much smaller particles (mostly to $<0.1$ to $4 \mu \mathrm{m}$ in size) than the original sulfide. The distribution of particle size is an important parameter for determining particle dynamics, displacement, deposition, and the aerosol stay duration in the atmosphere. The size of the metallic particles is prime for human incorporation. The finest size metallic particles are more easily to be inhaled, ingested, and absorbed by dermal contact. For example, fine $(<2.5 \mathrm{~mm})$ particles can penetrate the smaller airways in the peripheral lung region close to alveolar interstitium, while ultrafine $(<0.1 \mathrm{~mm}$ ) particles can penetrate until the alveolar interstitium (Fig. 2). In the alveolar region of the lungs, the rate of absorption of $\mathrm{Pb}$ particles is about $32 \%$ of the deposition in the lungs (USEPA, 1994). Also, the finest particles absorb more heavy metals in comparison to coarse-grained ones, which is attributed to the larger surface areas of their components (Witt et al., 2014).

Deposition of inhaled particles along the human respiratory tract based on the particles size fraction: (1) > 10 mm: inhalable since they can easily enter the nose and mouth, $(2)<10 \mathrm{~mm}\left(\mathrm{PM}_{10}\right)$ : thoracic since they can penetrate deep in the respiratory system and generally deposited by impaction in the extra thoracic airway region, (3) < $4 \mathrm{~mm}$ : respirable because they are small enough to pass completely through the respiratory system and enter the bloodstream and are deposited by impaction in the tracheobronchial airway in the deep lungs, $(4)<2.5 \mathrm{~mm}\left(\mathrm{PM}_{2.5}\right)$ : fine because penetrate the smaller airways and are deposited by sedimentation in the peripheral lung region in the tracheobronchial airway close to alveolar interstitium, and $(5)<0.1 \mathrm{~mm}$ $\left(\mathrm{PM}_{0.1}\right)$ : ultrafine because penetrate the smaller airways and is deposited by diffusion often in the alveolar interstitium (Hussain et al., 2011; Brown et al., 2013; Ching and Mizuo, 2018).

\section{Conclusions}


In Torreón, the presence of Pb-rich particles historically emitted continue in the modern urban dust and because $\mathrm{Pb}$ is a persistent pollutant with limited mobility, the pollution will continue for centuries unless major abatement operations are employed. Knowledge of the long-term weathering alterations of metal-rich particles emitted from non-ferrous smelting and refining operations is useful to understand the mechanisms by which PTEs are released into the environment.

In the present, significant amounts of metal-rich particles occur in the urban dust surrounding Met-Mex in Torreón, including a lot of Pb-rich particles, which show a variety of size, morphology, and elemental and mineral composition. Analysis of particle size distribution, morphology, and elemental and mineral composition by using SEM-EDS and X-ray powder diffraction (XRD) techniques evidenced alterations by weathering processes on Pb-rich particles. The weathering of $\mathrm{Pb}$-rich particles is reducing the particle sizes (Pb-rich particles to finer particles), increasing the presence of secondary minerals such as $\mathrm{Pb}$ carbonates, $\mathrm{Pb}$ sulfate, and $\mathrm{Pb}$ oxides containing highest $\mathrm{Pb}$ contents. All physical-chemical transformations on the weathered $\mathrm{Pb}$ rich particles are increasing the solubility and availability of the $\mathrm{Pb}$ in the urban environment in Torreón exacerbating the toxicity and human health impact in the population.

\section{Declarations}

Acknowledgment: Thanks to H. Bójorquez-Leyva and C.L. Jocobi-Aguilar (Lab support), and Y. Montano-Ley (data processing) for their collaboration on this research.

Funding: INFRA-CONACYT 230061 and Sabbatical fellowship to M.F. Soto-Jiménez from PASPA-DGAPA-UNAM $2018-2019$.

Conflicts of interest: none.

Consent to participate: NA.

Consent to publish: NA.

Availability of data and material: Included in this work.

Code availability: Not applicable.

Author contributions: MFSJ is the Principal Investigator conducting this research. SRM and SSM contributed to the processing samples and LEGL and LBG are responsible for the SEM, SEM-EDS and XRD analysis. All authors contributed writing the manuscript.

Ethics approval: Not applicable.

\section{References}

1. Adamo, P., Dudka, S., Wilson, M. J., \& McHardy, W. J. Chemical and mineralogical forms of Cu and Ni in contaminated soils from the Sudbury mining and smelting region, Canada. Environ. Poll. 91(1), 11-19. https://doi.org/10.1016/0269-7491(95)00035-P (1996).

2. Argyraki, A. Garden soil and house dust as exposure media for lead uptake in the mining village of Stratoni, Greece. Environ. Geochem. Health, 36(4), 677-692. https://doi.org/10.1007/s10653-013-9589-9 (2014).

3. Benin, A. L., Sargent, J. D., Dalton, M., \& Roda, S. High concentrations of heavy metals in neighborhoods near ore smelters in northern Mexico. Environm. Health Persp., 107(4), 279-284. https://doi.org/10.1289/ehp.99107279 (1999).

4. Bern, A. M., Lowers, H. A., Meeker, G. P., \& Rosati, J. A. Method development for analysis of urban dust using scanning electron microscopy with energy dispersive X-ray spectrometry to detect the possible presence of World Trade Center dust constituents. Environ. Sci. Technol., 43(5), 14491454. https://doi.org/10.1021/es800865n (2009).

5. Birmili, W., Allen, A. G., Bary, F., \& Harrison, R. M. Trace metal concentrations and water solubility in size-fractionated atmospheric particles and influence of road traffic. Environ. Sci. Technol., 40(4), 1144-1153. https://doi.org/10.1021/es0486925 (2006).

6. Bollhöfer, A., \& Rosman, K. J. R. Isotopic source signatures for atmospheric lead: the Northern Hemisphere. Geochem. Cosmoch. Acta, 65(11), 17271740. https://doi.org/10.1016/S0016-7037(00)00630-X (2001).

7. Bosso, S. T., \& Enzweiler, J. Bioaccessible lead in soils, slag, and mine wastes from an abandoned mining district in Brazil. Environm. Geochem. Health, 30(3), 219-229. https://doi.org/10.1007/s10653-007-9110-4 (2008).

8. Brown, J. S., Gordon, T., Price, O., \& Asgharian, B. Thoracic and respirable particle definitions for human health risk assessment. Particle Fibre Toxicol., 10(1), 1-12. https://doi.org/10.1186/1743-8977-10-12 (2013).

9. Casteel, S. W., Weis, C. P., Henningsen, G. M., \& Brattin, W. J. Estimation of relative bioavailability of lead in soil and soil-like materials using young swine. Environm. Health Persp., 114(8), 1162-1171. https://doi.org/10.1289/ehp.8852 (2006).

10. Ching, J., Kajino, M. Aerosol mixing state matters for particles deposition in human respiratory system. Scientific Reports 8,8864 https://doi.org/10.1038/s41598-018-27156-z (2018).

11. Chopin, E. I. B., \& Alloway, B. J. Trace element partitioning and soil particle characterisation around mining and smelting areas at Tharsis, Ríotinto and Huelva, SW Spain. Sci. Total Environ., 373(2-3), 488-500. https://doi.org/10.1016/j.scitotenv.2006.11.037 (2007).

Page $8 / 14$ 
12. Csavina, J., Landázuri, A., Wonaschütz, A., Rine, K., Rheinheimer, P., Barbaris, B., Conant, W., Sáez, A. E., \& Betterton, E. A. Metal and metalloid contaminants in atmospheric aerosols from mining operations. Water, Air, Soil Poll., 221(1), 145-157. https://doi.org/10.1007/s11270-011-0777-x (2011).

13. Csavina, J., Field, J., Taylor, M. P., Gao, S., Landázuri, A., Betterton, E. A., \& Sáez, A. E. A review on the importance of metals and metalloids in atmospheric dust and aerosol from mining operations. Sci. Total Environ., 433, 58-73. https://doi.org/10.1016/j.scitotenv.2012.06.013 (2012).

14. Csavina, J., Taylor, M. P., Félix, O., Rine, K. P., Sáez, A. E., \& Betterton, E. A. Size-resolved dust and aerosol contaminants associated with copper and lead smelting emissions: implications for emission management and human health. Sci. Total Environ., 493, 750-756. https://doi.org/10.1016/j.scitotenv.2014.06.031 (2014).

15. Cusano, G., Rodrigo-Gonzalo, M., Farrell, F., Remus, R., Roudier, S., \& Delgado-Sancho, L. Best available techniques (BAT) Reference Document for the Non-Ferrous Metals Industries Industrial Emissions Directive 2010/75/EU. Integrated Pollution Prevention and Control. https://doi.org/10.2760/8224 (2017).

16. Escobar-Márquez, R., Borja-Espinosa, M., Viniegra, G., Cantellano-Alvarado, L., Antopia-Orta, L., \& Silva, F. Estudio Epidemiológico de la metalúrgica Peñoles. Salud Pública de México Epoca V.6, 387-403 (1964).

17. Ettler, V., Vaněk, A., Mihaljevič, M., \& Bezdička, P. Contrasting lead speciation in forest and tilled soils heavily polluted by lead metallurgy. Chemosphere, 58(10), 1449-1459. https://doi.org/10.1016/j.chemosphere.2004.09.084 (2005).

18. Ettler, V., Konečný, L., Kovářová, L., Mihaljevič, M., Šebek, O., Kříbek, B., Majer, V., Veselovský, F., Penížek, V., Vaněk, A., \& Nyambe, I.. Surprisingly contrasting metal distribution and fractionation patterns in copper smelter-affected tropical soils in forested and grassland areas (Mufulira, Zambian Copperbelt). Sci. Total Environ., 473, 117-124. https://doi.org/10.1016/j.scitotenv.2013.11.146 (2014a).

19. Ettler, V., Vítková, M., Mihaljevič, M., Šebek, O., Klementová, M., Veselovský, F., Vybíral, P., \& Kř́bek, B. Dust from Zambian smelters: mineralogy and contaminant bioaccessibility. Environm. Geochem. Health, 36(5), 919-933. https://doi.org/10.1007/s10653-014-9609-4 (2014b).

20. Ettler, V. Soil contamination near non-ferrous metal smelters: a review. Applied Geochem., 64, 56-74. https://doi.org/10.1016/j.apgeochem.2015.09.020 (2016).

21. Ettler, V., Štěpánek, D., Mihaljevič, M., Drahota, P., Jedlicka, R., Kříbek, B., Vaněk, A., Penižek, V., Sracek, O., Nyambe, I. Slag dusts from Kabwe (Zambia): Contaminant mineralogy and oral bioaccessibility. Chemosphere, 260, 127642. https://doi.org/10.1016/j.chemosphere.2020.127642 (2020)

22. Gasser, U. G., Walker, W. J., Dahlgren, R. A., Borch, R. S., \& Burau, R. G. Lead release from smelter and mine waste impacted materials under simulated gastric conditions and relation to speciation. Environ. Sci. Technol., 30(3), 761-769. https://doi.org/10.1021/es940737m (1996).

23. Gregurek, D., Melcher, F., Pavlov, V. A., Reimann, C., \& Stumpfl, E. F. Mineralogy and mineral chemistry of snow filter residues in the vicinity of the nickel-copper processing industry, Kola Peninsula, NW Russia. Mineral. Petrol., 65, 87-111 (1999).

24. Gregurek, D., Reimann, C., \& Stumpfl, E. F. Mineralogical fingerprints of industrial emissions -an example from Ni mining and smelting on the Kola Peninsula, NW Russia. Sci. Total Environ., 221(2-3), 189-200. https://doi.org/10.1016/S0048-9697(98)00293-9 (1998).

25. Gulson, B. L., Davis, J. J., Mizon, K. J., Korsch, M. J., \& Bawden-Smith, J. Sources of lead in soil and dust and the use of dust fallout as a sampling medium. Sci. Total Environ., 166(1-3), 245-262. https://doi.org/10.1016/0048-9697(95)04505-U (1995).

26. Gulson, B. L., Mahaffey, K. R., Mizon, K. J., Korsch, M. J., Cameron, M. A., \& Vimpani, G. Contribution of tissue lead to blood lead in adult female subjects based on stable lead isotope methods. J. Lab. Clin. Med., 125, 703-712 (1995).

27. Henderson, P. J., McMartin, I., Hall, G. E., Percival, J. B., \& Walker, D. A. The chemical and physical characteristics of heavy metals in humus and till in the vicinity of the base metal smelter at Flin Flon, Manitoba, Canada. Environ. Geol., 34, 39-58 (1998).

28. Hettiarachchi, G. M., \& Pierzynski, G. M. Soil lead bioavailability and in situ remediation of lead-contaminated soils: A review. Environ. Progress, 23(1), 78-93. https://doi.org/10.1002/ep.10004 (2004).

29. Hussain, M., Madl, P. \& Khan, A. Lung deposition predictions of airborne particles and the emergence of contemporary diseases, Part-I. Health 2(2), 51-59 (2011).

30. Industrias Peñoles S.A. de C.V. Peñoles Annual Report. Industrias Peñoles Website; http://www.penolescommx/penoles/ingles/images/press (2017).

31. Industrias Peñoles S.A. de C.V. Peñoles Annual Report. Industrias Peñoles Website; http://www.penolescommx/penoles/ingles/images/press (2018).

32. International Centre for Diffraction Data (ICDD). Retrieved February 2019, from https://www.icdd.com/ (2019)

33. Instituto Nacional de Estadística y Geografia (INEGI). Retrieved May 11, 2021, from https://www.inegi.org.mx (2021)

34. Knight, R. D., \& Henderson, P. J. Characterization of smelter dust from the mineral fraction of humus collected around Rouyn-Noranda, Quebec. https://doi.org/10.4095/221133 (2005).

35. Knight, R. D., \& Henderson, P. J. Smelter dust in humus around Rouyn-Noranda, Quebec. Geochem. Explor. Environ. Analysis, 6(2-3), $203-214$. https://doi.org/10.1144/1467-7873/05-087 (2006).

36. Lanteigne, S., Schindler, M., McDonald, A. M., Skeries, K., Abdu, Y., Mantha, N. M., Murayama, M., Hawthorne, F. C., \& Hochella M. F. Mineralogy and weathering of smelter-derived spherical particles in soils: implications for the mobility of $\mathrm{Ni}$ and $\mathrm{Cu}$ in the surficial environment. Water Air Soil Poll., 223(7), 3619-3641. https://doi.org/10.1007/s11270-012-1135-3 (2012).

Page 9/14 
37. Lanteigne, S., Schindler, M., \& McDonald, A. Distribution of metals and metalloids in smelter-derived particulate matter in soils and mineralogical insights into their retention and release in a low-T environment. Can. Mineral., 52(3), 453-471. https://doi.org/10.3749/canmin.52.3.453 (2014).

38. Manceau, A., Lanson, B., Schlegel, M. L., Harge, J. C., Musso, M., Eybert-Berard, L., Hazemann, J. L., Chateigner, D., \& Lamble, G. M. Quantitative Zn speciation in smelter-contaminated soils by EXAFS spectroscopy. Amer. J. Sci., 300(4), 289-343. https://doi.org/10.2475/ajs.300.4.289 (2000).

39. Marcosson, I. F. Metal magic, the story of the American smelting and refining company. Farrar, Straus, and Company; First edition (1949).

40. Ohmsen, G. S. Characterization of fugitive material within a primary lead smelter. J. Air Waste Manag. Assoc., 51(10), $1443-1451$. https://doi.org/10.1080/10473289.2001.10464371 (2001).

41. Piatak, N. M., \& Seal II, R. R. Mineralogy and the release of trace elements from slag from the Hegeler Zinc smelter, Illinois (USA). Applied Geochem., 25(2), 302-320. https://doi.org/10.1016/j.apgeochem.2009.12.001 (2010).

42. Piatak, N. M., Seal II, R. R., \& Hammarstrom, J. M. Mineralogical and geochemical controls on the release of trace elements from slag produced by base-and precious-metal smelting at abandoned mine sites. Applied Geochem., 19(7), 1039-1064.

https://doi.org/10.1016/j.apgeochem.2004.01.005 (2004).

43. Root, R. A., Hayes, S. M., Hammond, C. M., Maier, R. M., \& Chorover, J. Toxic metal (loid) speciation during weathering of iron sulfide mine tailings under semi-arid climate. Applied Geochem., 62, 131-149. https://doi.org/10.1016/j.apgeochem.2015.01.005 (2015).

44. Ruby, M. V., Schoof, R., Brattin, W., Goldade, M., Post, G., Harnois, M., Mosby, D. E., Casteel, S. W., Berti, W., Carpenter, M., Edwards, D., Cragin, D. \& Chappell, W. Advances in evaluating the oral bioavailability of inorganics in soil for use in human health risk assessment. Environ. Sci. Techn., 33(21), 3697-3705. https://doi.org/10.1021/es990479z (1999).

45. Rucker, M. L. Earthwork factors in weathered granites by geophysics. In Use of Geoph. Meth. Const., (pp. 201-214). https://doi.org/10.1061/40521(296)14 (2000).

46. Shukurov, N., Kodirov, O., Peitzsch, M., Kersten, M., Pen-Mouratov, S., \& Steinberger, Y. Coupling geochemical, mineralogical and microbiological approaches to assess the health of contaminated soil around the Almalyk mining and smelter complex, Uzbekistan. Sci. Total Environ., 476, 447459. https://doi.org/10.1016/j.scitotenv.2014.01.031 (2014).

47. Sobanska, S., Ricq, N., Laboudigue, A., Guillermo, R., Brémard, C., Laureyns, J., Merlin, J. C., \& Wignacourt, J. P. Microchemical investigations of dust emitted by a lead smelter. Environ. Sci. Techn., 33(9), 1334-1339. https://doi.org/10.1021/es9805270 (1999).

48. Sobanska, S., Deneele, D., Barbillat, J., \& Ledésert, B. Natural weathering of slags from primary Pb-Zn smelting as evidenced by Raman microspectroscopy. Applied Geochem., 64, 107-117. https://doi.org/10.1016/j.apgeochem.2015.09.011 (2016).

49. Soto-Jimenez, M. F., \& Flegal, A. R. Childhood lead poisoning from the smelter in Torreón, México. Environ. Res., $111(4), 590-596$. https://doi.org/10.1016/j.envres.2011.01.020 (2011a).

50. Soto-Jiménez, M. F., \& Flegal, A. R. Metal-contaminated indoor and outdoor housedust from a neighborhood Smelter area in Torreón, Mexico. Proc. Environ. Sci., 4, 134-137. https://doi.org/10.1016/j.proenv.2011.03.016 (2011b).

51. Soto-Jiménez, M. F., \& Flegal, A. R. Inventory of Pb emissions from one of the largest historic Pb smelter worldwide: 118-year legacy of Pb pollution in northern Mexico. Environ. Sci. Poll. Res., 28(16), 20737-20750. https://doi.org/10.1007/s11356-020-11788-8 (2021).

52. Spear, T. M., Svee, W., Vincent, J. H., \& Stanisich, N. Chemical speciation of lead dust associated with primary lead smelting. Environ. Health Persp., 106(9), 565-571. https://doi.org/10.1289/ehp.98106565 (1998).

53. U.S. Environmental Protection Agency (USEPA) Guidance manual for the integrated exposure uptake biokinetic model for lead in children. EPA/540/R-93/081. Washington: U.S. Environmental Protection Agency (1994).

54. Valdés-Perezgasga, F., \& Cabrera-Morelos, V. M. La contaminación por metales pesados en Torreón, Coahuila, México. Texas Center for Policy Studies, CILADHAC, Torreón, Coah. (1999).

55. Viniegra, G., Escobar, R., Borja, E., \& Caballero, P. J. La polución atmosférica e hídrica de Torreón, Coah. Salud Pública de México. Epoca V. 6, 405414 (1964).

56. Witt III, E. C., Wronkiewicz, D. J., Pavlowsky, R. T., \& Shi, H. Trace metals in fugitive dust from unsurfaced roads in the Viburnum Trend resource mining District of Missouri-Implementation of a direct-suspension sampling methodology. Chemosphere, 92(11), 1506-1512. https://doi.org/10.1016/j.chemosphere.2013.04.012 (2013).

57. Witt III, E. C., Shi, H., Wronkiewicz, D. J., \& Pavlowsky, R. T. Phase partitioning and bioaccessibility of Pb in suspended dust from unsurfaced roads in Missouri-A potential tool for determining mitigation response. Atmos. Environ., 88, 90-98. https://doi.org/10.1016/j.atmosenv.2014.02.002 (2014).

\section{Figures}



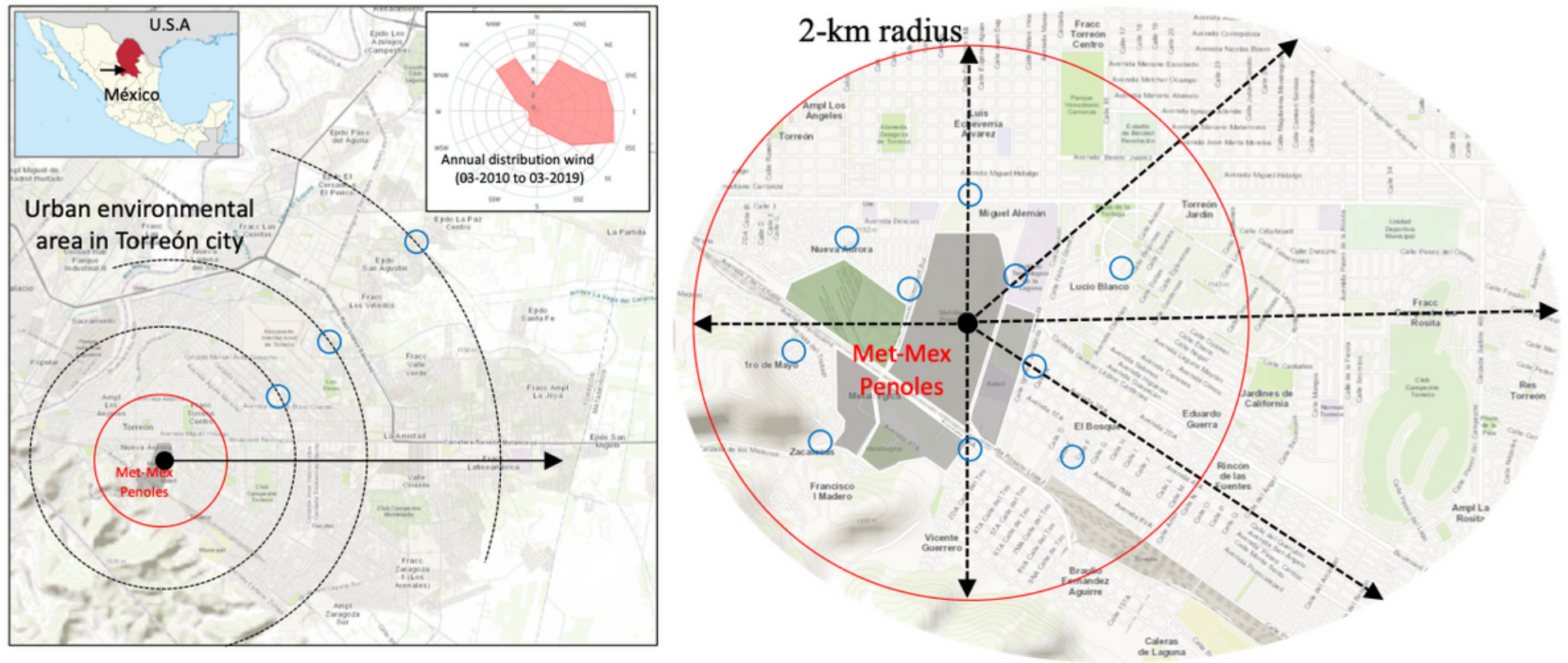

Figure 1

Urban environmental area in Torreón city (northern México), localization of Met-Mex metallurgical complex, and urban dust fall collection sites (blue circles) in the

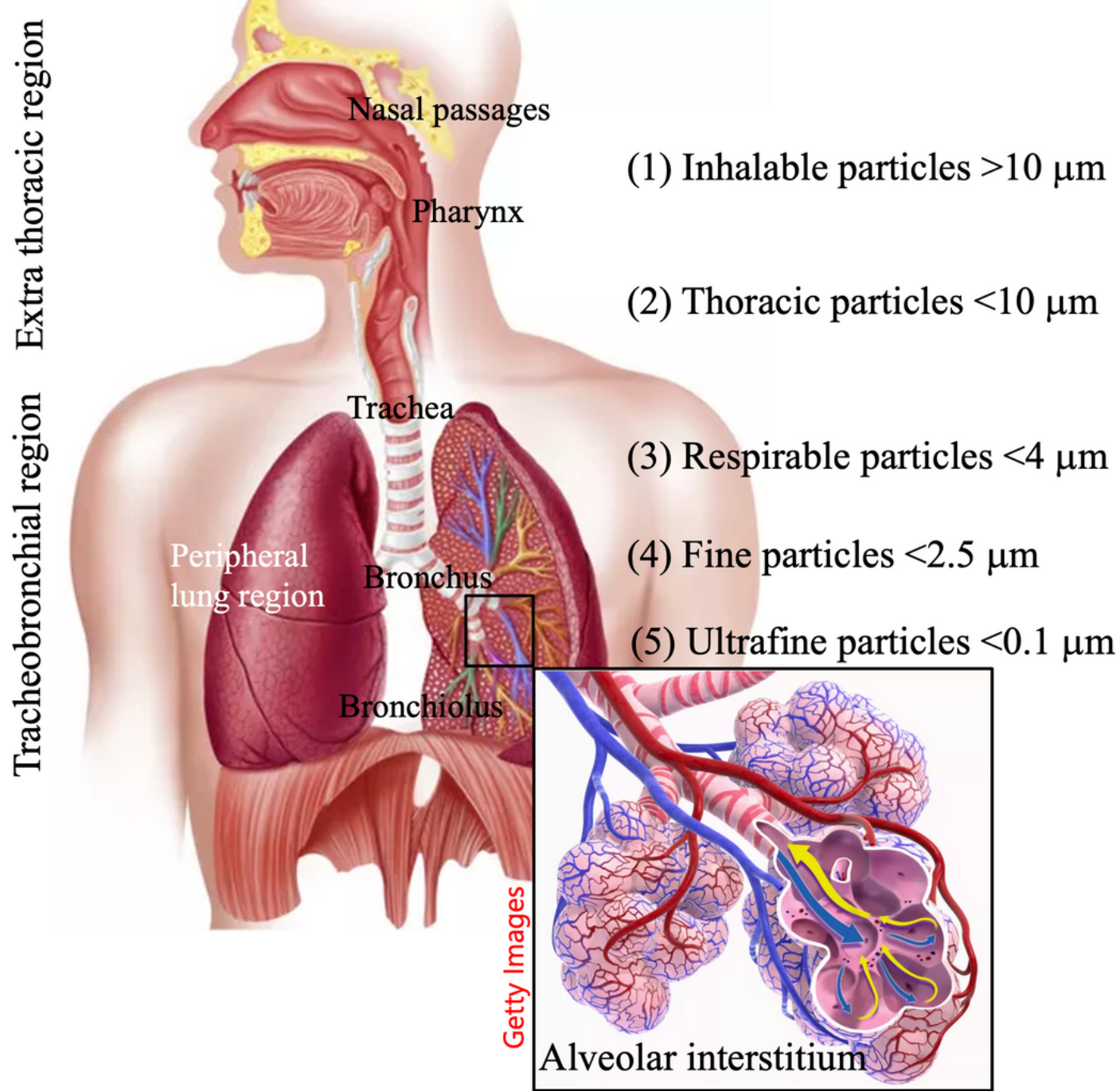


Deposition of inhaled particles along the human respiratory tract based on the particles size fraction: (1) > $10 \mu \mathrm{m}$ : inhalable since they can easily enter the nose and mouth, (2) <10 $\mu \mathrm{m}$ (PM10): thoracic since they can penetrate deep in the respiratory system and generally deposited by impaction in the extra thoracic airway region, (3) $<4 \mu \mathrm{m}$ : respirable because they are small enough to pass completely through the respiratory system and enter the bloodstream and are deposited by impaction in the tracheobronchial airway in the deep lungs, $(4)<2.5 \mu \mathrm{m}$ (PM2.5): fine because penetrate the smaller airways and are deposited by sedimentation in the peripheral lung region in the tracheobronchial airway close to alveolar interstitium, and (5) <0.1 $\mu \mathrm{m}$ (PM0.1): ultrafine because penetrate the smaller airways and is deposited by diffusion often in the alveolar interstitium (Hussain et al., 2011; Brown et al., 2013; Ching and Mizuo, 2018).
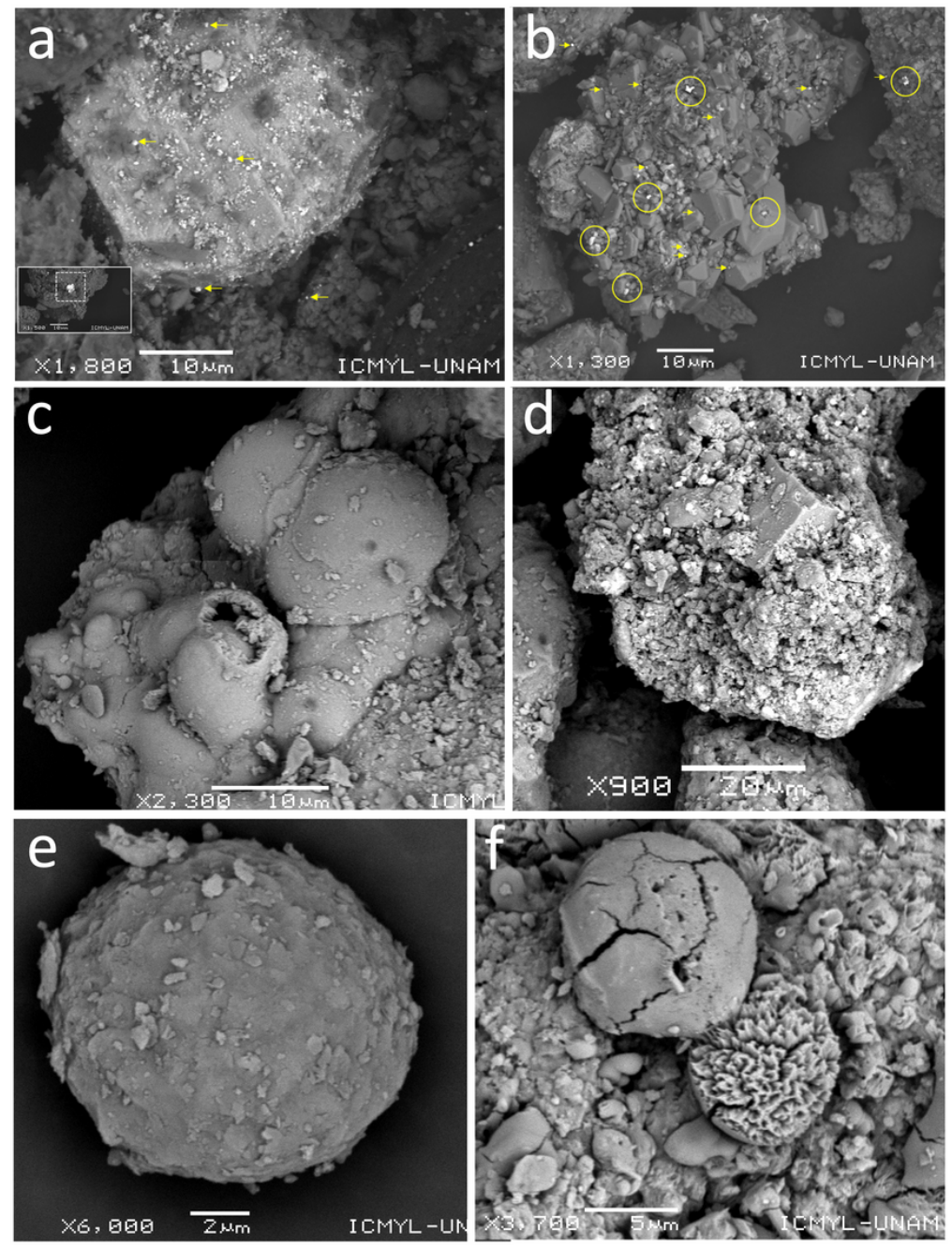

\section{Figure 3}

Micromorphology of metal-rich particles in urban dust observed by SEM: a) small Pb-rich particles adhered to coarse smelter slag, b) small Pb-rich particles incorporated to unaltered sulfides from concentrate ores, c) metal-rich agglomerates particle, d) galena incorporated into metal-rich agglomerates particle, e) small spherical metal-rich particle, f). spherical metal-particles into metal-rich agglomerates slag. 

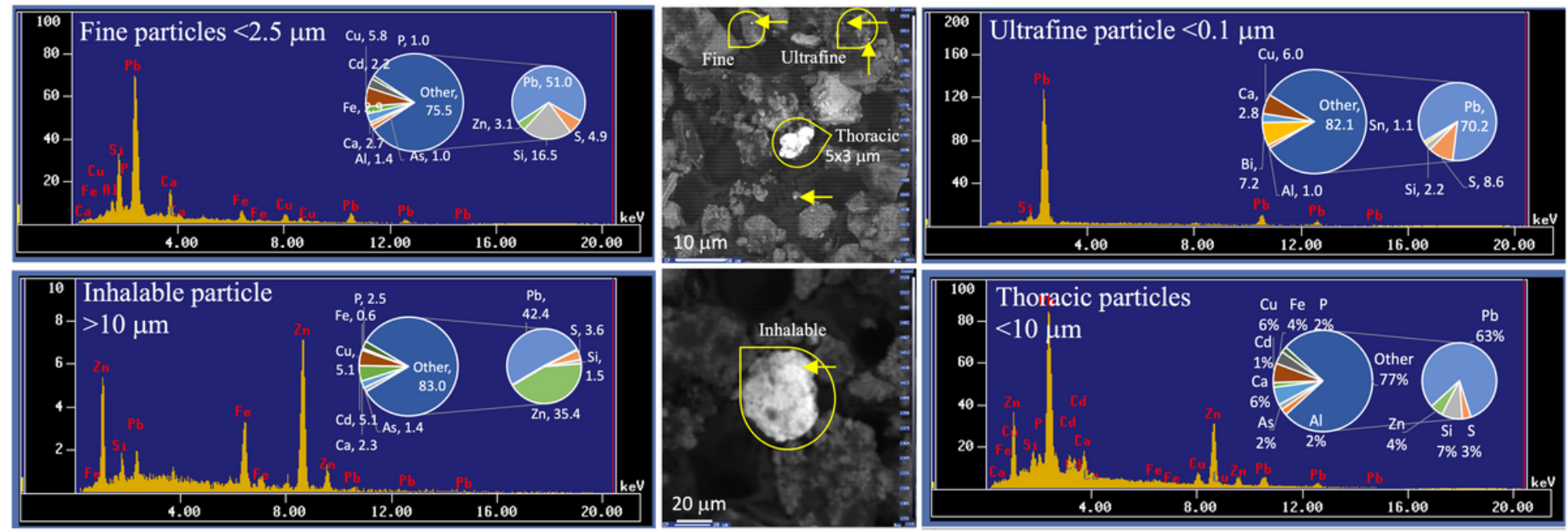

Figure 4

Energy Dispersive X-Ray Spectroscopy spectrum in conjunction with scanning electron microscopy and elemental composition (\% weight) of Pb-rich particles in urban dust collected in adjacent site to the smelter (TP1-3).
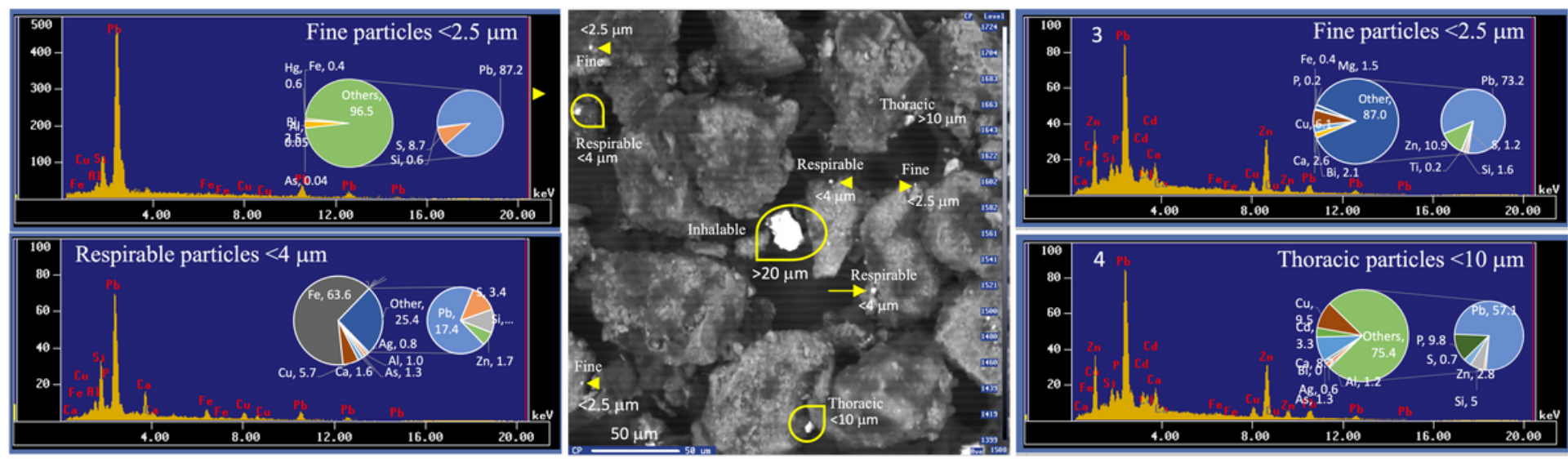

Figure 5

Energy Dispersive X-Ray Spectroscopy spectrum in conjunction with scanning electron microscopy and elemental composition (\% weight) of Pb-rich particles in urban dust collected in adjacent site to the smelter (TP2-3).

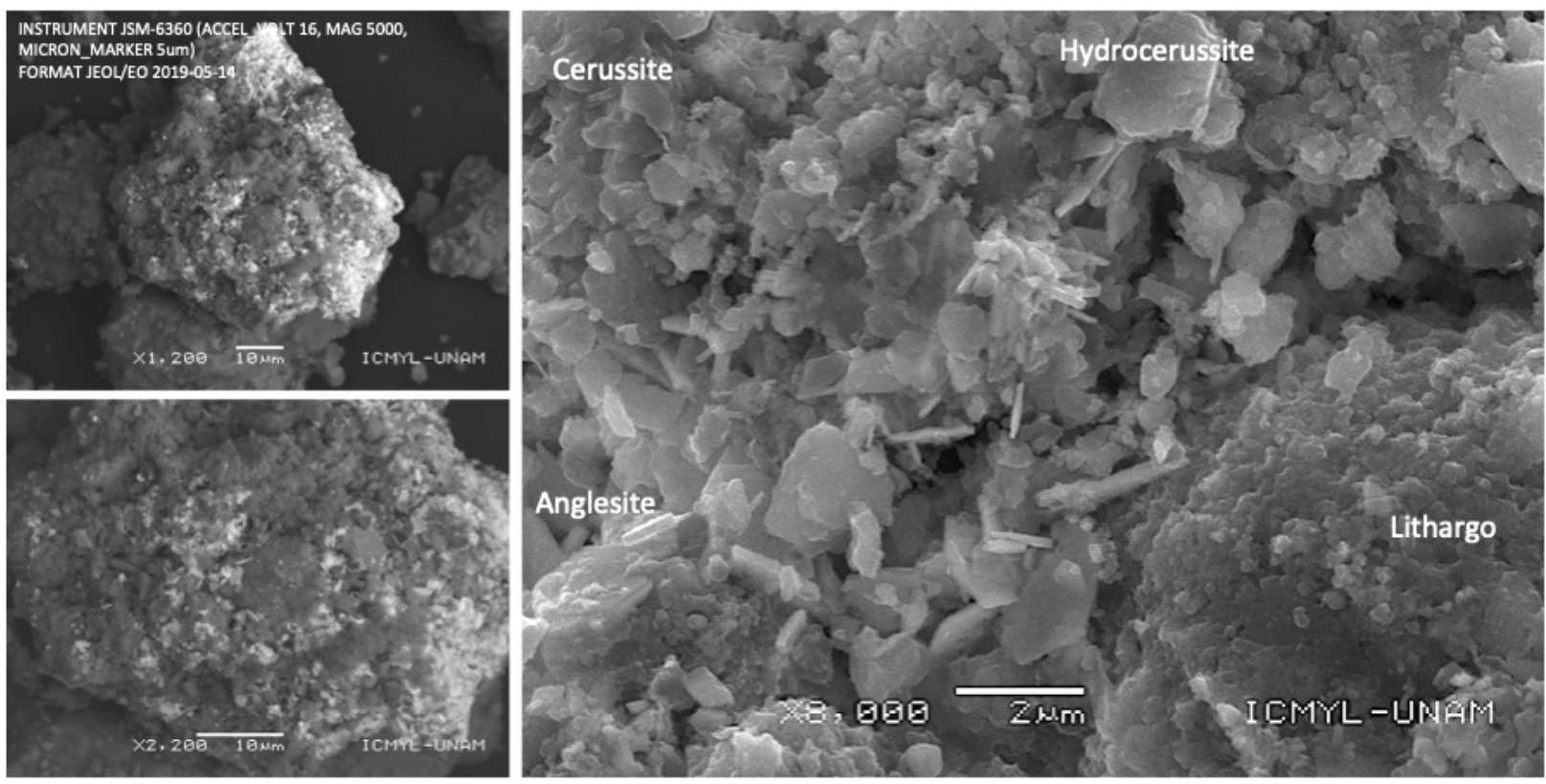




\section{Figure 6}

Surface morphology and secondary phases onto weathered Pb-rich particles in urban dust collected in the vicinity of Met-Mex as observed by SEM. The presence of $\mathrm{Pb}$ carbonate minerals (cerussite, hydrocerussite), $\mathrm{Pb}$-sulfate (anglesite), and $\mathrm{Pb}$-oxides (lithargo) were identified in weathered $\mathrm{Pb}$-rich particles. 